\title{
A successful cesarean section in a pregnant woman with A (H1N1) influenza requiring ECMO support
}

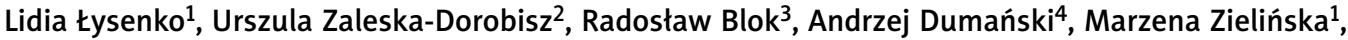 \\ Wojciech Kustrzycki ${ }^{4}$, Grażyna Durek ${ }^{1}$ \\ ${ }^{1}$ Department and Second Clinic of Anaesthesiology and Intensive Therapy, Medical University of Wroclaw, \\ Poland \\ 2Department of General and Pediatric Radiology, Medical University of Wroclaw, Poland \\ ${ }^{3} 1^{\text {st }}$ Department and Clinic of Gynecology and Obstetrics, Medical University of Wroclaw, Poland \\ ${ }^{4}$ Department and Clinic of Cardiac Surgery, Medical University of Wroclaw, Poland
}

Kardiochirurgia i Torakochirurgia Polska 2014; 11 (2): 216-219

\begin{abstract}
A 24-year-old pregnant woman (29.4 weeks of gestation) with A (H1N1) influenza-associated adult respiratory distress syndrome was admitted to the intensive care unit. The patient was connected to femoral-jugular veno-venous extracorporeal membrane oxygenation (ECMO) 8 hours after admission. On the $7^{\text {th }}$ day of ECMO support, due to the increasing threat to the life of the mother and the fetus, a decision was made to carry out a cesarean section (CS) without discontinuing the ECMO support. The CS was performed uneventfully under general anesthesia, 5 hours after the discontinuation of heparin infusion. A live, premature $1200 \mathrm{~g}$ female neonate was delivered. No complications occurred in the perioperative period. On the $17^{\text {th }}$ day, the patient was successfully weaned off the ECMO and discharged 10 days later. The newborn was discharged from the hospital in good health 41 days after the delivery.

Key words: influenza, pregnancy, ECMO, cesarean section.
\end{abstract}

\section{Introduction}

The influenza A ( $\mathrm{H} 1 \mathrm{~N} 1)$ virus was identified as the cause of the pandemic of 2009. As is the case with seasonal influenza, the pandemic virus A ( $\mathrm{H} 1 \mathrm{~N} 1)$ carried the risks of serious complications requiring treatment in an intensive care unit (ICU); pregnant and postpartum women were included in the risk group [1]. Pregnancy is associated with immunological changes, such as increased ventilatory demand as well as decreased functional residual capacity and oncotic pressure, which constitute predisposing factors for serious complications in pregnant and postpartum women when exposed to respiratory infection caused by an influenza virus [1, 2]. Primary viral pneumonia, which leads to

\section{Streszczenie}

Ciężarna, lat 24, w 29,4 tygodniu ciąży z objawami ostrej niewydolności oddechowej dorosłych w przebiegu zakażenia wirusem grypy A (H1N1) została przyjęta na oddział intensywnej terapii. Osiem godzin po przyjęciu chorej rozpoczęto udowo-szyjne, żylno-żylne przezmembranowe natlenianie pozaustrojowe (ECMO). W 7. dobie leczenia, w związku z narastającym zagrożeniem życia matki i płodu, podjęto decyzję o wykonaniu cięcia cesarskiego (CS) bez wyłączania ECMO. Odstawiono wlew heparyny i po 5 godzinach, w znieczuleniu ogólnym, wykonano CS. Urodziła się dziewczynka, żywa, niedonoszona, o wadze $1200 \mathrm{~g}$. W okresie okołooperacyjnym nie obserwowano powikłań. W 17. dobie leczenia pacjentka została z sukcesem odłączona od ECMO, a 10 dni później wypisana do domu. Dziecko w dobrym stanie ogólnym zostało wypisane do domu 41 dni po urodzeniu.

Słowa kluczowe: grypa, ciąża, ECMO, cięcie cesarskie.

the development of adult respiratory distress syndrome (ARDS), is the most serious complication of influenza. The treatment of ARDS should be comprehensive and include a pharmacological strategy (anti-viral and antibiotic treatment), a non-pharmacological strategy (lung protective strategy, recruitment maneuvers, prone position ventilation), and verification of the diagnosis with a real-time reverse transcriptase-polymerase chain reaction (RT-PCR) assay, as well as a therapy adjunctive to mechanical ventilation - nitric oxide, extracorporeal membrane oxygenation (ECMO), arterial venous carbon dioxide removal, and high-frequency oscillatory ventilation. The following report describes the case of a pregnant woman who developed

Address for correspondence: Lidia Łysenko, MD, PhD, Department and First Clinic of Anaesthesiology and Intensive Therapy, Medical University of Wroclaw, Chałubińskiego 1a, 50-368 Wrocław, Poland 
ARDS as a complication resulting from influenza A (H1N1) and was successfully treated with ECMO, during which an emergency cesarean section (CS) was performed.

\section{Case report}

In March 2011, a 24-year-old pregnant woman (29.4 weeks of gestation), primigravida, was admitted to the ICU of a teaching hospital with symptoms of acute respiratory failure, having been transferred from the department of internal medicine of a district hospital. In anamnesis, the patient had been ill for the previous 5 days, exhibiting signs of acute upper respiratory tract infection, for which she had been treated on an outpatient basis with antibiotics and antipyretic medication. On admission to the ICU, the patient was in a critical condition, under analgosedation, intubated, and on mechanical ventilation. The mechanical ventilation settings were: controlled mandatory ventilation, volume control, fraction of inspired oxygen $\left(\mathrm{FiO}_{2}\right)-1.0$, positive end-expiratory pressure (PEEP) $-5.0 \mathrm{cmH}_{2} \mathrm{O}$, tidal volume (TV) $-550 \mathrm{~mL}$, respiratory rate $(\mathrm{RR})-22$ per minute, with plateau pressure in the respiratory tract (Pplat) $-34 \mathrm{cmH}_{2} \mathrm{O}$, and compliance $-19 \mathrm{~mL} / \mathrm{cmH}_{2} \mathrm{O}$. Blood pressure was $120 /$ $75 \mathrm{mmHg}$ (without catecholamines), sinus tachycardia was 140 beats per minute (bpm), diuresis $-80-100 \mathrm{~mL}$ per hour, and body temperature $-36.6^{\circ} \mathrm{C}$. Extensive crackling could be heard over both lung fields. Arterial blood gas (ABG) showed profound hypoxia with an oxygenation index $\mathrm{PaO}_{2} / \mathrm{FiO}_{2}$ of 48.1, pH of 7.317, and normocapnia. The patient's plain chest PA X-ray image taken on admission to the ICU showed diffuse, almost homogeneous opacity of both lungs (Fig. 1).

Lung injury score was established at 3.25 points, which indicated a diagnosis of ARDS. Laboratory tests showed elevated levels of inflammatory response (C-reactive protein, CRP - $195.3 \mathrm{mg} / \mathrm{L}, \mathrm{N}:<10 \mathrm{mg} / \mathrm{L}$ ) and infection parameters (procalcitonin, PCT - $0.49 \mathrm{ng} / \mathrm{mL}, \mathrm{N}$ : $<0.05 \mathrm{ng} / \mathrm{mL}$ ). The consulting gynecologist found no signs of threatened premature delivery. A decision was made to delay the delivery. Pneumonia was suspected as a complication resulting from the influenza $A(\mathrm{H} 1 \mathrm{~N} 1)$ virus; treatment with oseltamivir, empiric piperacillin/tazobactam, and azithromycin was started. A virological examination was performed using the RT-PCR assay, giving a positive result for the presence of the influenza $A(\mathrm{H} 1 \mathrm{~N} 1)$ virus. Although the parameters of mechanical ventilation were modified (TV of approximately $6 \mathrm{~mL} / \mathrm{kg})$, high Pplat $\left(37 \mathrm{cmH}_{2} \mathrm{O}\right)$ and low compliance $(17.7 \mathrm{~mL} /$ $\left.\mathrm{cmH}_{2} \mathrm{O}\right)$ were observed. The $\mathrm{ABG}\left(\mathrm{FiO}_{2} 1.0\right)$ showed $\mathrm{PaO}_{2}$ of $48 \mathrm{mmHg}, \mathrm{paCO}_{2}$ of $48.7 \mathrm{mmHg}$, and $\mathrm{pH}$ of 7.304. A decision was made to place the patient on femoral-jugular veno-venous ECMO, which was commenced 8 hours after admitting the patient to the ICU. Once the ECMO was started, the patient required systemic heparinization. The ECMO flow was kept at $5.4 \mathrm{~L} / \mathrm{min}$ (cardiac index $-4.56 \mathrm{l} / \mathrm{min} / \mathrm{m}^{2}$ ) with 4500 revolutions per minute; protective lung ventilation was applied (pressure-controlled ventilation) with $\mathrm{FiO}_{2}$ - 0.3, Pplat - $20 \mathrm{cmH}_{2} \mathrm{O}, \mathrm{RR}-10$ per minute, PEEP - $10 \mathrm{~cm}$ $\mathrm{H}_{2} \mathrm{O}$, and $\mathrm{PaO}_{2}$ kept at $70 \mathrm{mmHg}$. On the first day of ECMO support, the patient developed symptoms of acute kidney insufficiency, and renal replacement therapy with the use of continuous veno-venous hemodiafiltration was started and maintained for three days until normal diuresis was observed. The values of inflammation and infection parameters gradually dropped. The patient received two $12 \mathrm{mg}$ doses of dexamethasone separated by a one-day interval to accelerate fetal lung maturity. Fetal heart rate (FHR) monitoring was carried out every 2 hours, while cardiotocography (CTG) recordings were performed 2 times a day. On day 6 of ECMO support, an elevation in body temperature $\left(38.8^{\circ} \mathrm{C}\right)$ and an increase in inflammation and infection parameters occurred (CRP $-131 \mathrm{mg} / \mathrm{L}, \mathrm{PCT}-0.46 \mathrm{ng} / \mathrm{mL}$ ). The results of microbiological tests were negative. The antibiotic therapy was modified - piperacillin/tazobactam and azithromycin were discontinued, and empiric linezolid, cilastatin/imipenem, and fluconazole were commenced. The CTG recordings detected silent oscillation and FHR of $180 \mathrm{bpm}$. On day 7 , the FHR was $190 \mathrm{bpm}$. A decision was made to perform a cesarean section (CS) without disconnecting the ECMO. The CS (30.3 weeks of gestation) was uneventfully performed under general anesthesia after a five-hour discontinuation of heparin infusion. A female neonate was delivered with Apgar scores of 2 and 5 (respectively at 1, and 5 minutes of life) and a weight of $1200 \mathrm{~g}$. Endotracheal intubation and mechanical ventilation of the newborn were started immediately after delivery. The neonate was transferred to the pediatric ICU for further treatment. Heparin infusion was restarted 14 hours after completing the CS. No bleeding or thromboembolic events within the ECMO circuit were reported. On day 8, the test for the influenza A (H1N1) virus using an RT-PCR assay was repeated; the result was positive. For this reason, oseltamivir was discontinued and zanamivir inhalation was started. On day 10 of ECMO support, the patient's fever subsided. On day 14 , a plain chest PA X-ray demonstrated increased aeration in the middle and upper parts of both lung fields with a regression of intra-alveolar changes. Inflammation and infection parameters returned to normal. A 15-day follow-up test was performed with the RT-PCR assay for the presence of the influenza A (H1N1) virus. The result was negative and zanamivir was discon-

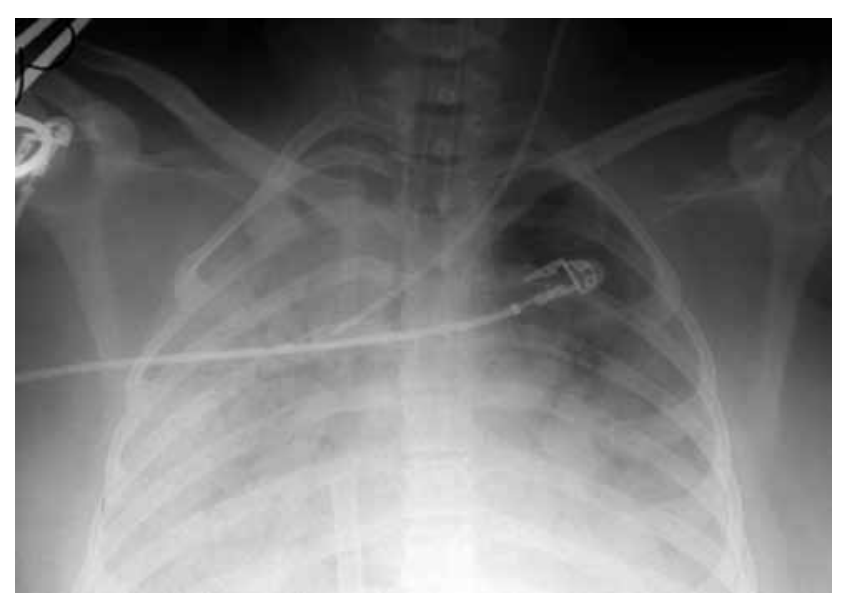

Fig. 1. Plain chest PA X-ray on admission to the ICU shows diffuse, almost homogeneous opacity of both lungs 


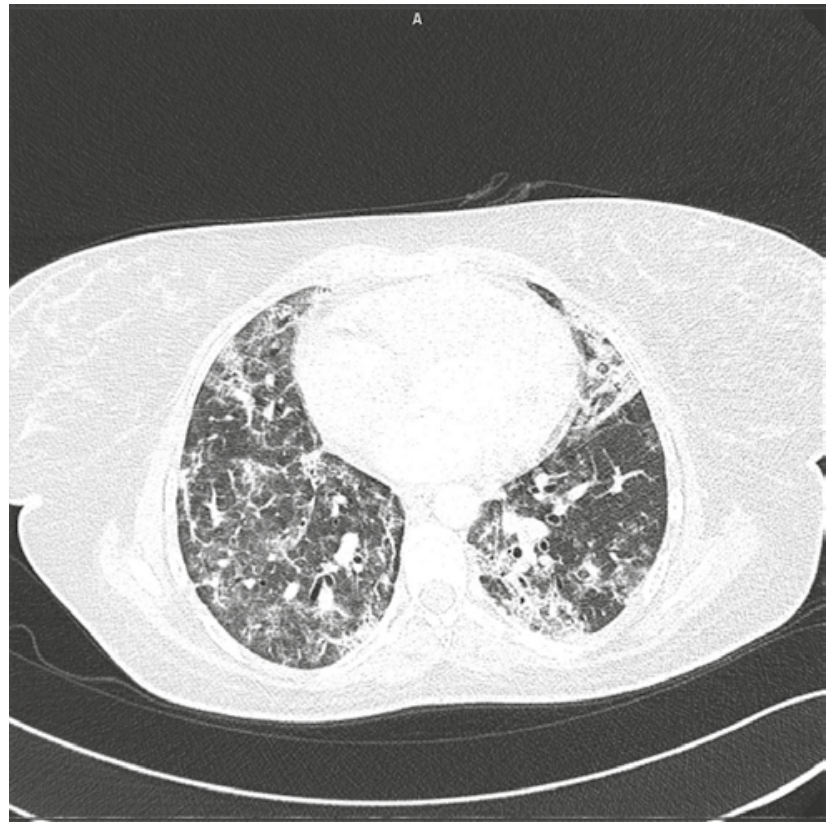

Fig. 2. CT of the lungs on the $23^{\text {rd }}$ day of treatment shows bilateral multilobar infiltrates and radiological symptoms of ARDS

tinued. On day 17 , the patient was successfully weaned off the ECMO. After two more days, the patient was extubated, and empirical antibiotic therapy was discontinued. On day 23, computed tomography (CT) of the chest was performed, confirming the presence of bilateral multi-lobar infiltrates and radiological symptoms of ARDS (Fig. 2).

On day 27 , the patient was discharged in good health. The newborn, having reached a weight of $2000 \mathrm{~g}$, was discharged from the hospital in good health after 41 days. Three months after discharge from the hospital, the mother underwent a follow-up CT chest scan and spirometry. The CT scan revealed regression of the changes in the lungs after treatment (Fig. 3). The spirometry tests did not indicate any abnormalities.

\section{Discussion}

Influenza A (H1N1) infection during pregnancy carries risks for the mother and the fetus. The rate of hospital admission for pregnant women with influenza $A(\mathrm{H} 1 \mathrm{~N} 1)$ is higher than for non-pregnant women. During the $2009 \mathrm{flu}$ pandemic caused by the $A(\mathrm{H} 1 \mathrm{~N} 1)$ virus, studies showed that pregnant women were 7.2 times more likely to be hospitalized and 4.3 times more likely to be admitted to an ICU than non-pregnant women [3]. Mortality among pregnant women with influenza $A(\mathrm{H} 1 \mathrm{~N} 1)$ who had required treatment in the ICU varied according to different sources from 8 to $17.6 \%[1,2,4]$. In one group of patients, which included pregnant women, the conventional treatment for ARDS that developed as a result of influenza $A(H 1 N 1)$ was ineffective, and it was then necessary to use ECMO as a rescue therapy [4-6]. This paper presents the use of ECMO on a pregnant woman suffering from ARDS that developed as a result of influenza $A(H 1 N 1)$ infection. In a case such as this, starting ECMO saves the life of the mother, but exposes the fetus to

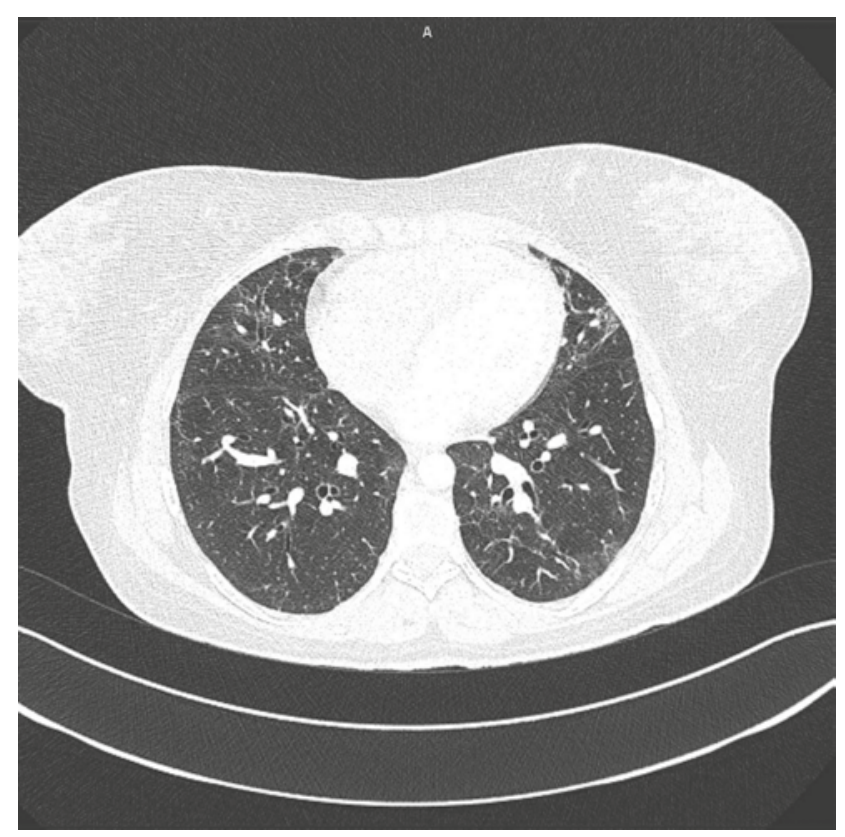

Fig. 3. CT of the lungs 3 months after hospital discharge shows the regression of the changes in the lungs after treatment

complications associated with systemic heparinization and extracorporeal circulation. Using the quickest possible intervention to deliver the fetus may shorten the ECMO use. It is, however, best to take the risk of starting ECMO, so that the child can reach a later gestational age, which increases the chance of survival. In the case described in this study, a CS was successfully performed using ECMO, and the decision to do this was taken due to the increasing threat to the life of the mother and the fetus. Previously, only one other similar case of performing a CS while using ECMO was mentioned in the scientific literature [7]. In other cases of pregnant women with influenza $A(H 1 N 1)$ requiring the use of ECMO that have been described to date, CS was performed either before starting ECMO or after its discontinuation [4]. The decision to perform a CS while the patient was on ECMO was not easy due to the increased risk of thrombosis from the required duration of heparin discontinuation. Major operations have been successfully performed under urgent conditions with temporary discontinuation of heparin infusion during the use of ECMO [8-10].

The case presented in this article ended with complete success for both the mother and the child. It seems that, while keeping the pros and cons fully in mind, it is worthwhile in certain situations to take the risk of performing a CS while ECMO is being administered. Certainly, the new generation of equipment for ECMO reduces the risk of complications from bleeding or thromboembolic events and makes the procedure safer.

\section{References}

1. Louie JK, Acosta M, Jamieson DJ, Honein MA. Severe 2009 H1N1 influenza in pregnant and postpartum Women in California. NEJM 2012; 362: 27-35.

2. Jamieson DJ, Honein MA, Rasmussen SA, Williams JL, Swerdlow DL, Biggerstaff MS, Lindstrom S, Louie JK, Christ CM, Bohm SR, Fonseca VP, Ritger KA, 
Kuhles DJ, Eggers P, Bruce H, Davidson HA, Lutterloh E, Harris ML, Burke C, Cocoros N, Finelli L, MacFarlane KF, Shu B, Olsen SJ. H1N1 2009 influenza virus infection during pregnancy in the USA. Lancet 2009; 374: 451-458.

3. Creanga AA, Johnson TF, Graitcer SB, Hartman LK, Al-Samarrai T, Schwarz AG, Chu SY, Sackoff JE, Jamieson DJ, Fine AD, Shapiro-Mendoza CK, Jones LE, Uyeki TM, Balter S, Bish C, Finelli L, Honein MA. Severity of 2009 pandemic influenza A (N1N1) virus infection in pregnant women: New York City, MayJune 2009. Obstet Gynecol 2010; 115: 717-726.

4. Fine A, Dentinger C, Johnson TF, Kossowski A, Steiner-Sichel L, Schwarz AG, Hartman LK, Honein MA, Jamieson D, Uyeki T, Al-Samarrai T, Creanga AA, Graitcer SB. 2009 pandemic influenza A (HH1N1) in pregnant women requiring intensive care - New York City, 2009. MMWR 2010; 59: 321-326.

5. Critical Care Services and 2009 H1N1 influenza in Australia and New Zealand. The ANZIC Influenza Investigators. N Engl J Med 2009; 361: 1925-1934.

6. Grasselli G, Foti G, Patroniti N, Giuffrida A, Cortinovis B, Zanella A, Pagni F, Mergoni M, Pesci A, Pesenti A. A case of ARDS associated with influenza
A-H1N1 infection treated with extracorporeal respiratory support. Minerva Anestesiol 2009; 5: 741-745.

7. Panarello G, Ancona GD, Capitanio G, Occhipinti G, Attardo G, Bertani A, Arcadipane A. Cesarean section during ECMO support. Minerva Anestesiol 2011; 77: 654-657.

8. Noorani A, Vuylsteke A, Lewis C, Parameshwar J, Catarino P. A moribund athlete. Lancet 2012; 380: 74.

9. Huang PM, Ko WJ, Tsai PR, Kuo SW, Hsu HH, Chen JS, Lee JM, Lee YC. Aggressive management of massive hemothorax in patients on extracorporeal membrane oxygenation. Asian J Surg 2012; 35: 16-22.

10. Lamb K, Cowan S, Evans N, Pitcher H, Moritz T, Lazar M, Hirose H, Cavarocchi $N$. Successful management of bleeding complications in patients supported with extracorporeal membrane oxygenation with primary respiratory failure. Perfusion 2012; 28: 125-131. 